\title{
OPTIMIZATION OF ANALYTICAL METHODS FOR THE DETERMINATION OF TRACE CONCENTRATIONS OF TOXIC POLLUTANTS IN DRINKING AND SURFACE WATERS
}

\author{
T.D. LEKKAS \\ M. KOSTOPOULOU \\ G. KOLOKYTHAS \\ N. THOMAIDIS \\ S. GOLFINOPOULOS \\ A. KOTRIKLA \\ G. PAVLOGEORGATOS \\ A. STASINAKIS \\ A. NIKOLAOU* \\ G. GATIDOU \\ A. PETSAS \\ M. VAGI \\ D. BABOS \\ D. LEKKAS

\section{C.A. MAKRI}

Selected from papers presented at the $8^{\text {th }}$ Conference on Environmental Science and Technology, 8 - 10 September 2003, Lemnos, Greece.
University of the Aegean, Department of Environmental Studies Water and Air Quality Laboratory University Hill, 81100 Mytilene, Greece

*to whom all correspondence should be addressed: Tel: +(30) 22510 36225-7, fax: + (30) 22510-36226 e-mail: nnikol@aegean.gr

\begin{abstract}
Pollutants posing health risks to human health and to the aquatic environment often occur in drinking and surface waters, as a result of disinfection practices, agricultural and industrial activities, wastewater discharges. Toxic pollutants belong to different chemical categories, including chlorination by-products, volatile and semivolatile organic compounds, insecticides (organochlorine and organophosphorous), herbicides (triazines and substituted ureas), metals and organotin compounds. Optimization of different analytical methods needed for their laboratory determination is necessary, since most of these pollutants have toxic effects when they are present even at trace concentrations in water. The investigation described here includes optimization of analytical methods applied in the Water and Air Quality Laboratory of the University of the Aegean for determination of 130 toxic pollutants in water, by means of gas chromatography with ECD, NPD, FPD and MS detection, Purge and Trap concentration, high performance liquid chromatography (HPLC) with Diode Array Detection (DAD) and atomic absorption spectrometry (AAS). The methods described were selected for application to surface water and drinking water samples from Greece, after experimental modifications which resulted in the best analytical performance achievable with the particular instrumentation, expressed by the calculated recoveries and detection limits.
\end{abstract}

KEYWORDS: analytical methods, chlorination by-products, volatile organic compounds, insecticides, herbicides, metals, organotin compounds 


\section{INTRODUCTION}

A large number of toxic pollutants have been detected in drinking and surface waters worldwide, raising concerns about possible impacts on the environment and human health. Toxic pollutants including volatile and semivolatile organic compounds (VOCs), organochlorine and organophosphorous insecticides, herbicides, metals and organotin compounds (OTs) are released from various human activities, such as agriculture and industry. Another major category of compounds, chlorination by-products (CBPs) are formed during water disinfection, by reactions of chlorine with natural organic matter (Fent and Hunn, 1995; Albanis et al., 1998; Cancho et al., 1999; Golfinopoulos and Nikolaou, 2001; Richardson 2002; Cerejeira et al., 2003).

Many toxic pollutants have been regulated by the European Union, the United States Environmental Protection Agency and the World Health Organization (EEC, 1982; WHO, 1995; USEPA, 1998; EC, 2000). In order to obtain information about their occurrence in water, their levels, their transport and fate and their possible transformations, sensitive analytical methods are a necessary tool. The optimization of different analytical methods for the determination of toxic pollutants is an issue of critical importance, since it affects the capability of screening, quantifying and even minimizing their concentrations in water (by legal measures) (Lekkas, 2000a).

This work presents the results of the optimization efforts for ten analytical methods for the determination of 130 toxic pollutants in water (Table 1). The techniques utilized include gas chromatography (GC) with ECD, NPD, FPD and MS detection, Purge and Trap, high performance liquid chromatography (HPLC) with Diode Array Detection (DAD) and atomic absorption spectrometry (AAS). The objective was to obtain reliable methods that can be applied on a routine basis, providing acceptable recoveries and low detection limits (DLs). These methods are applied in the Water and Air Quality Laboratory of the University of the Aegean, where CBPs are analyzed monthly in chlorinated drinking water from Athens (25 sampling stations) (Golfinopoulos and Nikolaou, 2001), and the other toxic pollutants are analyzed seasonally in the surface waters of Greece, from the 53 sampling stations of the National Monitoring Network (Lekkas, 2000a).

\section{ANALYTICAL METHODS}

Glassware. All glassware was washed with detergent, rinsed with tap water, ultrapure water (Millipore: Milli-Ro 5 plus and Milli Q plus 185) and acetone (Mallinckrodt Chemical Works St. Louis) and placed in an oven at $105^{\circ} \mathrm{C}$ overnight.

\section{Chlorination by-products}

Sampling. Samples were collected in 40-ml amber glass bottles with polypropylene screw caps and TFE-faced septa (Pierce 13075), which were carefully filled just to overflow. The residual chlorine was quenched by addition of sodium sulfite for the volatile CBPs and ammonium chloride for HAAs (100 mg per liter of sample in both cases). Standard solutions. Stock solutions of volatile CBPs were prepared in methanol purge and trap grade (Sigma-Aldrich) by addition of certified CBPs standards (Chemservice, purity $>99 \%$ ). The nine haloacetic acids (HAAs) and their methyl esters in methyl-tert-butyl ether (MTBE) were purchased from Supelco and were accompanied with certificates of analysis (purity $>99 \%$ ). All stock solutions were stored at $4{ }^{\circ} \mathrm{C}$.

Sample preparation. A. Volatile CBPs. A modification of EPA Method 551.1 was performed (Nikolaou et al., 2002a). 6 g sodium sulfate anhydrous (Merck) and $2 \mathrm{ml}$ MTBE (Merck) were added to $35 \mathrm{ml}$ of CBPs solution in a 40-ml glass vial capped with PTFE-faced silica septum (Pierce 13075). The vial was sealed and shaken for $1 \mathrm{~min}$ and left undisturbed for $2 \mathrm{~min} .1 \mu \mathrm{l}$ of the ether phase was then injected into the GC.

B. HAAs. Acidic methanol esterification was applied (Nikolaou et al., 2002b). $30 \mathrm{ml}$ of sample were poured into a 40-ml amber glass vial and the following reagents were added: surrogate standard 1 ( $5 \mu \mathrm{l}$ of a solution of 2-bromopropionic acid $60 \mathrm{mg} \mathrm{l}^{-1}$ in MTBE), $3 \mathrm{ml}$ concentrated sulfuric acid (Merck) (so that $\mathrm{pH}<0.5$ ), $12 \mathrm{~g}$ of anhydrous sodium sulfate (Merck), $3 \mathrm{~g}$ copper (II) sulfate pentahydrate (Merck) and $2 \mathrm{ml}$ MTBE. The vial was sealed, shaken for 2 minutes, and allowed to stand for 5 minutes. $900 \mu \mathrm{l}$ of the extract was transferred into a 14-ml vial containing $2 \mathrm{ml}$ solution of sulfuric acid in methanol $(10 \%)$. After addition of surrogate standard $2(1 \mu$ l solution of 2,3-dibromopropionic acid $60 \mathrm{mg} \mathrm{l}^{-1}$ in MTBE), the vial was placed in a water bath at $50{ }^{\circ} \mathrm{C}$ for 1 $\mathrm{h}$. Then it was cooled to $4{ }^{\circ} \mathrm{C}$ for $10 \mathrm{~min}$ and $5 \mathrm{ml}$ of a copper (II) sulfate pentahydrate / anhydrous 
Table 1. Toxic pollutants analyzed with the optimized analytical methods

\begin{tabular}{|c|c|c|c|}
\hline$\overline{\text { CBPs }}$ & VOCs (continued) & Insecticides & Herbicides \\
\hline Volatile CBPs & 32.Dichloromethane & Organochlorine & 96.Simazine \\
\hline 1.Chloroform* & $\begin{array}{l}\text { 33.trans- } \\
\text { 1,2- Dichloroethene }\end{array}$ & 64.Heptachlor & 97.Atrazine \\
\hline 2.Dichlorobromomethane* & 34.1,1-Dichloroethane & 65.Heptachlor epoxide & 98.Monolinuron \\
\hline 3.Dibromochloromethane* & 35.cis- 1,2- Dichloroethene & 66. $\alpha$-Endosulfan & 99.Linuron \\
\hline 4.Bromoform* & 36.1,1,1-Trichloroethane & 67. $\beta$-Endosulfan & 100.Diuron \\
\hline 5.Monochloroacetonitrile & 37.Benzene & 68.Endosulfan sulfate & 101.Metobromuron \\
\hline 6.Trichloroacetonitrile & 38.1,2-Dichloropropane & 69.Endrin aldehyde & 102.Terbuthylazine \\
\hline 7.Dichloroacetonitrile & 39.Toluene & 70.Methoxychlor & 103.Prometryn \\
\hline 8.Chloral hydrate & 40.1,1,2-Trichloroethane & 71.Endrin ketone & 104.Cyanazine \\
\hline 9.1,1-Dichloropropanone & 41.1,2-Dibromoethane & 72.DDT & 105.Chlorotoluron \\
\hline 10.Monobromoacetonitrile & 42.Chlorobenzene & 73.HCH & 106.DeisopropylAtrazine \\
\hline 11.Chloropicrin & 43.Ethylbenzene & 74.Aldrin & 107.Metamitron \\
\hline 12.Bromochloroacetonitrile & 44. $(\mathrm{m}+\mathrm{p})$-Xylenes & 75.Dieldrin & 108.Chloridazon \\
\hline 13. Trichloropropanone & 45.o-Xylene & 76.Endrin & 109.DesethylAtrazine \\
\hline 14.1,3-Dichloropropanone & 46.Isopropylbenzene & 77.Isodrin & Metals \\
\hline 15.Dibromoacetonitrile & 47.2-Chlorotoluene & Organophosphorous & 110.As \\
\hline Haloacetic acids & 48.4-Chlorotoluene & 78.Methamidophos & 111.Cd \\
\hline 16.Monochloroacetic & 49.1,3-Dichlorobenzene & 79.Mevinphos & 112.Hg \\
\hline 17.Monobromoacetic & 50.1,4-Dichlorobenzene & 80.Omethoate & 113. Cr \\
\hline 18.Dichloroacetic & 51.1,2-Dichlorobenzene & 81.Demeton $(\mathrm{O}+\mathrm{S})$ & $114 . \mathrm{Cu}$ \\
\hline 19.Bromochloroacetic & 52.Napthalene & 82.Demeton-S-Methyl & 115.Co \\
\hline 20.Trichloroacetic & 53.Bromochloromethane & 83.Dimethoate & 116.Fe \\
\hline 21.Dibromoacetic & 54.Dibromomethane & 84.Disulfoton & 117.Pb \\
\hline 22.Bromodichloroacetic & 2.Dichlorobromomethane* & 85.Parathion methyl & 118.Mn \\
\hline 23.Dibromochloroacetic & 3.Dibromochloromethane* & 86.Fenitrothion & 119.Mo \\
\hline 24.Tribromoacetic acid & 55.2,2-Dichloropropane & 87.Malathion & 120.Ni \\
\hline VOCs & 56.1,1-Dichloropropene & 88.Fenthion & 121.V \\
\hline 25.Carbon tetrachloride & 57.1,3-Dichloropropane & 89.Parathion ethyl & 122.Zn \\
\hline 26.Hexachlorobenzene & 4.Bromoform* & 90.Triazophos & 123.Ti \\
\hline 27.Hexachlorobutadiene & 58.Bromobenzene & 91.Azinphos methyl & 124.Ba \\
\hline 1.Chloroform* & 59.n-Propylbenzene & 92.Azinphos ethyl & 125.Al \\
\hline 28.1,2-Dichloroethane & 60.tert-Butylbenzene & 93.Coumaphos & Organotins \\
\hline 29.Trichloroethylene & 61.sec-Butylbenzene & 94.Phoxim & 126. Monobutyltin \\
\hline 30.Tetrachloroethylene & 62.1,3,5-Trimethylbenzene & $\begin{array}{l}\text { Phenols } \\
\text { 95. Pentachloro- } \\
\text { phenol }\end{array}$ & $\begin{array}{l}\text { 128. Tributyltin } \\
\text { 129. Diphenyltin } \\
\text { 130. Triphenyltin }\end{array}$ \\
\hline
\end{tabular}

sodium sulfate solution $50 \mathrm{~g} \mathrm{l}^{-1}$ and $100 \mathrm{~g} \mathrm{l}^{-1}$ respectively in ultrapure water was added. The vial was shaken again for 2 minutes and allowed to stand for 5 minutes. $1 \mu \mathrm{l}$ of the final extract was injected into the GC.

Analytical. A Hewlett Packard Gas Chromatograph 5890 Series II with a 63Ni Electron Capture Detector (ECD) was used. The carrier gas was helium and the make-up gas nitrogen. The column used was fused silica DB-1, $30 \mathrm{~m}$ x $0.32 \mathrm{~mm}$ i.d. $\mathrm{x} 0.25 \mu \mathrm{m}$ film thickness. The injection tech- nique was split/splitless. The analytical conditions of the gas chromatograph are presented in Table 2

Table 2. Analytical conditions for the determination of CBPs

\begin{tabular}{lc}
\hline Carrier gas flow: & $1.6 \mathrm{ml}$ min-1 \\
Oven temperature: & $35^{\circ} \mathrm{C}(9 \mathrm{~min})$, with $1{ }^{\circ} \mathrm{C} \mathrm{min}-1$ \\
& to $40{ }^{\circ} \mathrm{C}(3 \mathrm{~min})$, with $6{ }^{\circ} \mathrm{C}$ \\
& min-1 to $220^{\circ} \mathrm{C}(10 \mathrm{~min})$ \\
Injector temperature: & $175^{\circ} \mathrm{C}$ \\
Split ratio: & $1: 25$ \\
Detector temperature: & $300^{\circ} \mathrm{C}$ \\
\hline
\end{tabular}


Table 3. Recoveries and detection limits for CBPs

\begin{tabular}{|c|c|c|c|c|c|c|c|}
\hline Compound & $\begin{array}{c}\text { Concentration } \\
\text { range }\left(\mu \mathrm{g} \mathrm{l}^{-1}\right)\end{array}$ & $\begin{array}{l}\text { Recovery } \\
\text { range }(\%)\end{array}$ & $\begin{array}{c}\text { DLs } \\
\left(\boldsymbol{\mu g} \mathbf{~ l}^{-1}\right)\end{array}$ & Compound & $\begin{array}{c}\text { Concentration } \\
\text { range }\left(\mu \mathrm{g} \mathrm{l}^{-1}\right)\end{array}$ & $\begin{array}{l}\text { Recovery } \\
\text { range }(\%)\end{array}$ & $\begin{array}{c}\text { DLs } \\
\left(\mu \mathrm{gl}^{-1}\right)\end{array}$ \\
\hline$\overline{\mathrm{CHCl3}}$ & $0.5-20.0$ & $90.0-110.8$ & 0.010 & $1,1,1-T C P$ & $0.5-20.0$ & $75.8-111.3$ & 0.040 \\
\hline $\mathrm{CHCl} 2 \mathrm{Br}$ & $0.5-20.0$ & $87.6-110.8$ & 0.005 & $1,3-D C P$ & $0.5-20.0$ & $88-100$ & 0.070 \\
\hline $\mathrm{CHClBr} 2$ & $0.5-20.0$ & $92.0-107.5$ & 0.007 & $D B A N$ & $0.5-20.0$ & $92.6-121.2$ & 0.070 \\
\hline $\mathrm{CHBr3}$ & $0.5-20.0$ & $94.7-112.8$ & 0.010 & $M C A$ & $1.5-9.0$ & $25.0-126.0$ & 0.20 \\
\hline$M C A N$ & $0.5-20.0$ & $60.4-139$ & 0.040 & $M B A$ & $1-6.0$ & $78.8-123.7$ & 0.05 \\
\hline$T C A N$ & $0.5-20.0$ & $97.2-118.2$ & 0.070 & $D C A$ & $1.5-9.0$ & $89.7-104.8$ & 0.02 \\
\hline$D C A N$ & $0.5-20.0$ & $62.6-124.3$ & 0.007 & $B C A$ & $1-6.0$ & $94.7-109.4$ & 0.02 \\
\hline $\mathrm{CH}$ & $0.5-20.0$ & $86.7-144.5$ & 0.007 & $T C A$ & $0.5-3$ & $87.8-117.7$ & 0.01 \\
\hline $1,1-D C P$ & $0.5-20.0$ & $83.7-120$ & 0.040 & $D B A$ & $0.5-3$ & $97.1-141.1$ & 0.02 \\
\hline$M B A N$ & $0.5-20.0$ & 87.9-131.2 & 0.040 & $B D C A$ & $1.0-6.0$ & $89.9-126.0$ & 0.10 \\
\hline$C P$ & $0.5-20.0$ & $58.7-124.2$ & 0.040 & $D B C A$ & $2.5-15.0$ & 78.1-135.9 & 0.20 \\
\hline$B C A N$ & $0.5-20.0$ & $82.5-143.2$ & 0.040 & $T B A$ & $5-30.0$ & 89.5-109 & 0.20 \\
\hline
\end{tabular}

and a representative chromatogram in Figure 1. Recoveries ranged from $87.6 \%$ to $112.8 \%$ for THMs, from $60.4 \%$ to $144.5 \%$ for the other CBPs and from $78.1 \%$ to $123.7 \%$ for HAAs (Table 3). Low recoveries of MCAN, 1,3-DCP and MCA have also been reported in the literature. 1,3-DCP is a volatile compound with decomposition trends, while the derivatization of MCA has been reported to be problematic by use of different derivatization agents (Cancho et al., 1999, Chen and Weisel, 1998). The DLs (estimated for signal-to-noise ratio 3/1) ranged from $0.005 \mu \mathrm{g} \mathrm{l}^{-1}$ to $0.070 \mu \mathrm{g} \mathrm{l}^{-1}$ for the volatile CBPs and from 0.01 to $0.2 \mu \mathrm{g} \mathrm{l}^{-1}$ for HAAs, therefore the method provides accurate measurements for the range of CBPs usually existing in drinking water, which generally has been reported to be above $0.5 \mu \mathrm{g} \mathrm{l}^{-1}$ for most of the compounds (Lekkas, 2003). The main advantages of these methods are the small sample volume required, which is convenient for routine (monthly) analysis, and the small amount of solvents used, which results in lower cost and lower analysis time since evaporation of the extracts is not necessary.

\section{Volatile and semivolatile organic compounds (VOCs)}

Sampling. Duplicate samples for VOCs measurement were collected in 40-ml glass vials and were capped with PTFE-faced silica septum (Pierce 13075). The vials were carefully filled just to overflow. $\mathrm{HCl}(4$ drops $6 \mathrm{~N} / 40 \mathrm{ml})$ was added to each water sample to prevent biodegradation and dehydrohalogenation.

Standard solutions. The accuracy of determinations is routinely checked by using standard solutions containing known amounts of VOCs. Standard solutions are prepared in ultrapure water by injecting known volumes of certified VOCs standards in methanol (Chemservice, purity $>99 \%$ ).

Analytical. The determination of VOCs is carried out by a modification of purge and trap-gas chromatography-mass spectrometry method (PATGC-MS) (Kostopoulou et al., 2000). The VOCs are analyzed using a Hewlett Packard Purge and Trap Concentrator 7695 fitted with a $30 \mathrm{~cm}$ absorbent trap (VOCARB3000), a Hewlett Packard Gas Chromatograph 5890 Series II and a Hewlett Packard Mass Spectrometer HP5971 MSD. The column used for the chromatographic separation of VOCs is a $60 \mathrm{~m} \times 0.32 \mathrm{~mm}$ i.d. $\mathrm{x} 1.8$ $\mu \mathrm{m}$ i.d. film thickness fused silica capillary HP VOC. Helium is used as the carrier gas, and the injection technique is split/splitless. The analytical conditions are shown in Table 4 and a representative chromatogram in Figure 2. The recoveries and detection limits of the compounds (estimated for signal-to-noise ratio 3/1) are presented in Table 5. The recoveries are relatively low, but it must be taken into account that the compounds are volatile and that the concentrations measured were very low. Several of these coumpounds cannot be determined with liquid-liquid extraction or with headspace GC-MS, as proved in our previous research (Golfinopoulos et al., 2001). The major advantages of the method is the elimination of the sample preparation step, and the elimination of use of toxic solvents. The detection limits, using the Selected Ion Monitoring (SIM) mode, range from $0.01 \mu \mathrm{g} \mathrm{l}^{-1}$ to $0.25 \mu \mathrm{g} \mathrm{l}^{-1}$. 


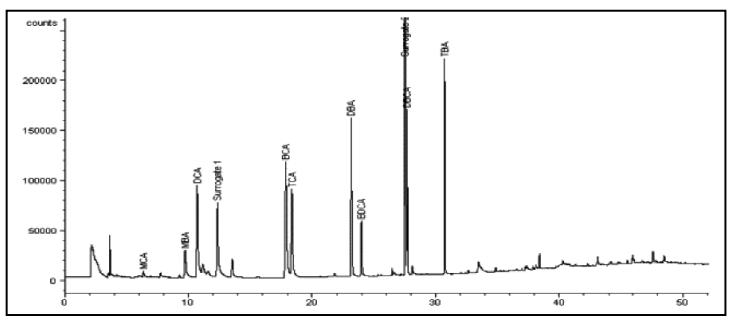

Figure 1: Typical GC-ECD chromatogram of derivatized HAAs standard solution, concentration 3-30 $\mu \mathrm{g} \mathrm{l^{-1 }}$.

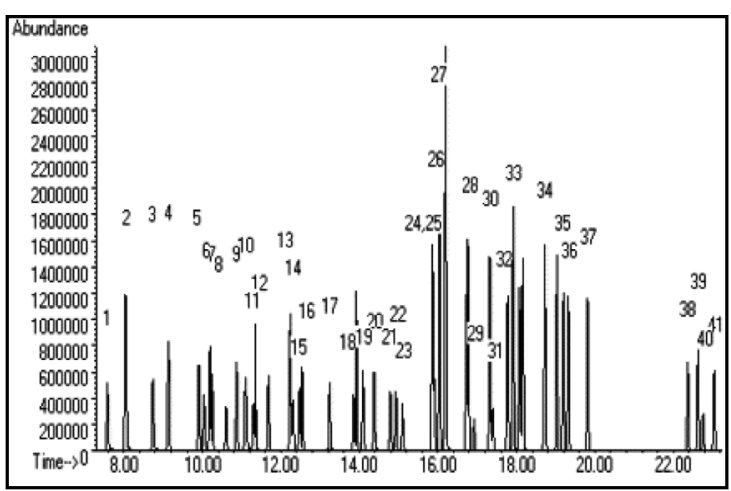

Figure 2: Typical PAT-GC-MS of VOCs standard solution, concentration $10 \mu \mathrm{g}^{\mathrm{l}-1}$.

\section{Insecticides}

Sampling. Water samples are collected in 1-1 amber glass vials. They are pre-filtered through $0.45 \mu \mathrm{m}$ glass fiber to eliminate particulate matter and acidified with hydrochloric acid $(6 \mathrm{~N})$ to $\mathrm{pH}=$ 2 , in order to inhibit biological activity.

Sample preparation. Solid-phase extraction procedure (SPE) is applied. Methanol modifier $(10 \mathrm{ml})$ is added to 11 water samples to allow better extraction (Albanis et al., 1998). SPE disks of $47 \mathrm{~mm}$ diameter and $0,5 \mathrm{~mm}$ thickness, containing $500 \mathrm{mg}$ of the bonded phase (octadecyl-C18- bonded silica), are used for sample preparation. The disks are condi- tioned with acetone $10 \mathrm{ml}$ for $30 \mathrm{~min}$ and placed in the conventional Millipore apparatus. Prior the extraction they are washed with $10 \mathrm{ml}$ of ethyl acetate followed by $10 \mathrm{ml}$ of dichloromethane under vacuum and with $10 \mathrm{ml}$ of methanol with the vacuum off. The SPE disks are not allowed to become dry, as recommended (Albanis et al., 1998). The water samples are mixed well and allowed to percolate through the disks with a flow rate of $30 \mathrm{ml}$ $\mathrm{min}^{-1}$ under vacuum. The insecticides trapped in the disk are collected by using $2 \times 5 \mathrm{ml}$ of ethyl acetate as eluting solvent. The eluted fractions are evaporated to $0.5 \mathrm{ml}$ in a gentle stream of nitrogen.

Analytical. The insecticide residues are analyzed by Gas Chromatography (GC) method using a Hewlett Packard Gas Chromatograph 5890 Series II, supported by a Nitrogen Phosphorus Detector (NPD) for the organophosphorus insecticides and an Electron Capture Detector (ECD) for the organochlorine insecticides. A $30 \mathrm{~m}$ x $0.32 \mathrm{~mm}$ i.d $\mathrm{x} 0.25 \mu \mathrm{m}$ film thickness fused silica capillary (DB5 ) is used for the chromatographic separation of the organophosphorus insecticides and a $30 \mathrm{mx}$ $0.53 \mathrm{~mm}$ i.d $\times 0.5 \mu \mathrm{m}$ film thickness fused silica capillary (HP-608) is used for the chromatographic separation of the organochlorine insecticides. The analytical conditions for determination of insecticides are given in Table 6 and a representative chromatogram in Figure 3. The detection limit for the organochlorine insecticides is 0.002 $\mu \mathrm{g} \mathrm{l}^{-1}$ and for the organophosphorus insecticides $0.003 \mu \mathrm{g} \mathrm{l}^{-1}$ except for methamidophos, meviphos, demeton $(\mathrm{O}+\mathrm{S})$, demeton-S-methyl, dimethoate $\left(0.005 \mu \mathrm{g} \mathrm{l}^{-1}\right)$ and omethoate $\left(0.05 \mu \mathrm{g} \mathrm{l}^{-1}\right)$. In the case of insecticides, minimization of sample volume or elimination of the evaporation step is not possible, since the regulatory limits (76/464/EEC) are very low, demanding detection limits similar to those obtained by the analysis of 1-1 water sample.

Table 4. Purge and trap-GC-MS method - analytical conditions

\begin{tabular}{ll}
\hline Purge: & $40 \mathrm{ml} \mathrm{min}{ }^{-1} \mathrm{He}, 11 \mathrm{~min}$, ambient temperature \\
Desorb: & $30 \mathrm{ml} \mathrm{min}{ }^{-1} \mathrm{He}, 180^{\circ} \mathrm{C}$ for $4 \mathrm{~min}$ (preheat $175^{\circ} \mathrm{C}$ ) \\
Bake: & $220^{\circ} \mathrm{C}$ for $10 \mathrm{~min}$ \\
Temperatures: & Line $200^{\circ} \mathrm{C}$, Valve $200^{\circ} \mathrm{C}$, Moisture Contr. Syst. (MCS) Line $200^{\circ} \mathrm{C}$ \\
Carrier gas flow & $1 \mathrm{ml} \mathrm{min}-1$ \\
Oven temperature & $35^{\circ} \mathrm{C} \mathrm{for} 3 \mathrm{~min}, 10^{\circ} \mathrm{C} \mathrm{min-1} \mathrm{to} 235^{\circ} \mathrm{C}$ \\
Injector temperature & $200^{\circ} \mathrm{C}$ \\
Split ratio & $1: 25$ \\
Solvent delay & 0 \\
MS operating mode & $S I M$ \\
EMV & 2200
\end{tabular}


Table 5. Recoveries and detection limits for VOCs (concentrations $0.5-10 \mu \mathrm{g} \mathrm{l}^{-1}$ )

\begin{tabular}{|c|c|c|c|c|c|}
\hline Compound & $\begin{array}{l}\text { Recovery } \\
\text { range }(\%)\end{array}$ & $\begin{array}{c}\text { DLs } \\
\text { range }\left(\mu \mathrm{l}^{-1}\right)\end{array}$ & Compound & $\begin{array}{c}\text { Recovery } \\
\text { range }(\%)\end{array}$ & $\begin{array}{c}\text { DLs } \\
\left(\mu \mathrm{g} \mathrm{l}^{-1}\right)\end{array}$ \\
\hline cis-1,2-dichloroethene & $47-120$ & 0.25 & Tetrachloroethene & $47-130$ & 0.1 \\
\hline Dichloromethane & $62-160$ & 0.05 & 1,2-dibromoethane & $67-130$ & 0.1 \\
\hline 1,1-dichloroethene & $54-141$ & 0.1 & Chlorobenzene & $57-140$ & 0.05 \\
\hline 1,1-dichloroethane & $55-130$ & 0.1 & Ethylbenzene & $49-145$ & 0.05 \\
\hline trans-1,2-dichloroethene & $59-140$ & 0.25 & $(m+p)$-xylenes & $49-147$ & 0.05 \\
\hline 2,2-dichloropropane & $50-125$ & 0.05 & o-xylene & $53-137$ & 0.05 \\
\hline Chloroform & $58-135$ & 0.1 & Bromoform & $67-135$ & 0.1 \\
\hline Bromochloromethane & $63-152$ & 0.25 & Isopropylbenzene & $47-125$ & 0.05 \\
\hline 1,1,1-trichloroethane & $49-125$ & 0.1 & Bromobenzene & $60-140$ & 0.1 \\
\hline 1,2-dichloroethane & $65-125$ & 0.1 & n-propylbenzene & $46-125$ & 0.05 \\
\hline Carbon tetrachloride & $48-135$ & 0.1 & 1,3,5-trimethylbenzene & $51-140$ & 0.25 \\
\hline Benzene & $50-147$ & 0.1 & 1,3-dichlorobenzene & $57-132$ & 0.05 \\
\hline Trichloroethene & $58-135$ & 0.05 & 1,4-dichlorobenzene & $59-135$ & 0.05 \\
\hline Dibromomethane & $66-140$ & 0.25 & 1,2-dichlorobenzene & $61-137$ & 0.1 \\
\hline Dichlorobromomethane & $60-160$ & 0.05 & 1,2,4-trichlorobenzene & $63-140$ & 0.01 \\
\hline 1,1,2-trichloroethane & $66-135$ & 0.1 & Napthalene & $76-140$ & 0.05 \\
\hline 1,3-dichloropropane & $65-125$ & 0.05 & Hexachlorobutadiene & $46-127$ & 0.25 \\
\hline Chlorodibromomethane & $64-132$ & 0.1 & 1,2,3-trichlorobenzene & $65-140$ & 0.01 \\
\hline
\end{tabular}

However, ethyl acetate, which has been reported to be a low toxicity solvent has been selected, and proved to provide good chromatography results. The percent recoveries of the insecticides at concentration levels $0.02-0.4 \mu \mathrm{g} \mathrm{l}^{-1}$ are presented in Table 7. The recoveries generally ranged from $40.3 \%$ (heptachlor) to $145.3 \%$ (dieldrin). Lower recoveries were observed for DDT and its metabolites $(26.8 \%-123.3 \%)$, HCH (34.8\%$168.2 \%)$ and isodrin $(19.8 \%-83.2 \%)$. The fact that the insecticide concentrations tested were very low, in combination with possible impurities during the SPE exctraction procedure can explain the poor recoveries observed in these cases.
Previous study for similar concentration levels, using $\mathrm{C} 18$ cartridges, had also resulted in low recoveries for DDT and its metabolites $(28.6 \%$ $82.0 \%$ ), but showed higher recovery for $\mathrm{HCH}$ $(85.8$ - 145.3) and lower recovery for aldrin (37.2 $\%-49.7 \%$ ) compared to the present method (Golfinopoulos et al., 2003).

\section{Herbicides and Phoxim}

Sampling. Water samples are collected in 1-1 amber glass vials and are filtered through $0.7 \mu \mathrm{m}$ glass microfiber filter.

Standard solutions. All the solvents used are suitable for HPLC analysis. Analytical standards of

Table 6. Analytical conditions for determination of insecticides

\begin{tabular}{|c|c|c|}
\hline Conditions & Organochlorine & Organophosphorous \\
\hline Initial temperature $\left({ }^{\circ} \mathrm{C}\right)$ / Time (min) & $80-1$ & $150-1$ \\
\hline Temperature increase rate $\left({ }^{O} \mathrm{C} \mathrm{min}^{-1}\right)$ & 30 & 2 \\
\hline $1^{\text {st }}$ temperature step $\left({ }^{O} \mathrm{C}\right) /$ Time $(\mathrm{min})$ & $180-0$ & $180-0$ \\
\hline Temperature increase rate $\left({ }^{O} \mathrm{C} \mathrm{min}^{-1}\right)$ & 5 & 5 \\
\hline $2^{\text {nd }}$ temperature step $\left({ }^{O} \mathrm{C}\right) /$ Time $(\mathrm{min})$ & $200-0$ & $200-0$ \\
\hline Temperature increase rate $\left({ }^{O} \mathrm{C} \mathrm{min}^{-1}\right)$ & 10 & 5 \\
\hline $3^{\text {rd }}$ temperature step $\left({ }^{\circ} \mathrm{C}\right) /$ Time $(\mathrm{min})$ & $260-3$ & $250-7$ \\
\hline Injector temperature $\left({ }^{O} C\right)$ & 250 & 240 \\
\hline Detector temperature $\left({ }^{O} \mathrm{C}\right)$ & 300 & 280 \\
\hline Carrier gas flow & $5 \mathrm{ml} \mathrm{min}^{-1}(\mathrm{He})$ & $20 \mathrm{ml} \mathrm{min}^{-1}(\mathrm{He})$ \\
\hline Makeup gas flow & $40 \mathrm{ml} \mathrm{min}^{-1}\left(\mathrm{~N}_{2}\right)$ & $1.5 \mathrm{ml} \mathrm{min}^{-1}\left(N_{2}\right)$ \\
\hline Hydrogen flow & - & $3.5 \mathrm{ml} \min -1\left(\mathrm{H}_{2}\right)$ \\
\hline Air flow & - & $100-120 \mathrm{ml} \mathrm{min}^{-1}$ (Air) \\
\hline Injection type & On-column & On-column \\
\hline
\end{tabular}


Table 7. Percent recoveries of insecticides (concentration levels 0.02 to $4 \mu \mathrm{g} \mathrm{l}^{-1}$ )

\begin{tabular}{lccc}
\hline Insecticides & Recovery range $(\boldsymbol{\%})$ & Insecticides & Recovery range $(\boldsymbol{\%})$ \\
\hline$H C B$ & $41.4-99.5$ & $4,4-D D E$ & $31.1-48.2$ \\
-HCH & $45.9-160.8$ & Dieldrin & $59.6-145.3$ \\
-HCH & $47.4-148.8$ & Endrin & $56.9-113.1$ \\
b-HCH & $34.8-84.9$ & $4,4-D D D$ & $45.5-80.2$ \\
Heptachlor & $40.3-114.0$ & $b-E n d o s u l f a n$ & $49.9-131.3$ \\
d-HCH & $50.8-168.2$ & $4,4-D D T$ & $26.8-123.3$ \\
Aldrin & $47.5-84.6$ & Endrin Aldehyde & $52.9-132.4$ \\
Isodrin & $19.8-83.2$ & Endosulfan Sulfate & $48.9-122.5$ \\
Heptachlor Epoxide & $49.9-126.8$ & Methoxychlor & $57.8-127.6$ \\
a-Endosulfan & $48.3-126.7$ & Endrin Ketone & $54.6-124.5$ \\
\hline
\end{tabular}

all the herbicides are supplied by $\mathrm{Dr}$ Ehrenstorfer, Germany and ChemService, USA. Sample preparation. The sample $(500 \mathrm{ml})$ is filtered through a GF/F $0.7 \mu \mathrm{m}$ glass microfiber filter (Whatman, England). C18 cartridges (Waters, USA) are conditioned with $10 \mathrm{ml}$ of methanol and $10 \mathrm{ml}$ of ultra pure water and the sample is loaded with an approximate flow rate of $10 \mathrm{ml} \mathrm{min}^{-1}$. The sorbent is washed with $5 \mathrm{ml}$ of water, and the herbicides are eluted with $6 \mathrm{ml}$ of acetonitrile. The acetonitrile is removed under a gentle stream of nitrogen, at $35{ }^{\circ} \mathrm{C}$, and the herbicides are reconstituted with $1 \mathrm{ml}$ of the initial mobile phase.

Analytical. The HPLC system consists of a 9012 pump, associated with a Polychrom 9065 diodearray detector (Varian, USA) and a Rheodyne 7161, $100 \mu$ l, loop injector (Rheodyne, USA). The column is a Zorbax SB - C18 $4.6 \mathrm{~mm} \times 15 \mathrm{~cm}(5 \mu \mathrm{m})$ connected with a Zorbax SB - C18 precolumn (Hewlett Packard, USA). Jones Chromatography, England supplied a 7980 column block heater. The temperature of the column is set at $40^{\circ} \mathrm{C}$. The chromatographic analysis is accomplished using a gradient program with a mobile phase of acetonitrile and water, at a flow rate of $1.2 \mathrm{ml} \mathrm{min}^{-1}$ (Kotrikla and Lekkas, 2001). The gradient program is $10 \%$ acetonitrile to $100 \%$ acetonitrile in 40 minutes. In order to attain maximum sensitivity, the quantitative measurements are made at $220 \mathrm{~nm}$ for triazines, at $244 \mathrm{~nm}$ for phenylureas and at $282 \mathrm{~nm}$ for phoxim with the external standard method and the correlation coefficients of the calibration graphs are always higher than 0.999. The recoveries of the compounds are calculated from spiked samples at concentrations of $0.1,0.5$ and $1.0 \mu \mathrm{g} \mathrm{l}^{-1}$. The average recoveries and the coefficients of variation are: deisopropyl atrazine 12.8 (5.2), metamitron 36.7 (3.7), chloridazon 49.2 (2.9), desethyl atrazine 34.3 (3.8). Low recoveries for these polar compounds are reported in the literature (Sabik and Jeannot, 2000) due to their weak interactions with the non-polar octadecyl moieties of the $\mathrm{C} 18$ cartridges. For the rest of the compounds, the recoveries ranged between 65.4 and $104.6 \%$ with an average value of $86.3 \%$ and a maximum coefficient of variation $10.9 \%$.

The detection limits are: $0.025 \mu \mathrm{g} \mathrm{l}^{-1}$ for simazine, cyanazine, atrazine, terbuthylazine, prometryne, $0.040 \mu \mathrm{g} \mathrm{l}^{-1}$ for chlorotoluron, monolinuron, diuron, metobromuron and linuron, $0.5 \mu \mathrm{g} \mathrm{l}^{-1}$ for phoxim and $0.2 \mu \mathrm{g} \mathrm{l}^{-1}$ for deisopropyl-atrazine, metamitron, chloridazon and desethyl-atrazine. These values could be compared to the European legislation concerning the quality of water designated for human consumption: The EEC Directive 80/778, establishes the maximum admissible concentration of each individual pesticide at $0.1 \mu \mathrm{g} \mathrm{l}^{-1}$ and the total amount of pesticides at $0.5 \mu \mathrm{g} \mathrm{l}^{-1}$ (Council of the EEC, 1980). In surface water, these limits are an order of magnitude higher (1-3 $\left.\mu \mathrm{g} \mathrm{l}^{-1}\right)$. Although phoxim is an organophosphorous insecticide, it was included in the multiresidue method developed for the analysis of herbicides because the response of the HPLC/DAD was better compared to the GC / NPD system, as shown during preliminary experiments in our laboratory.

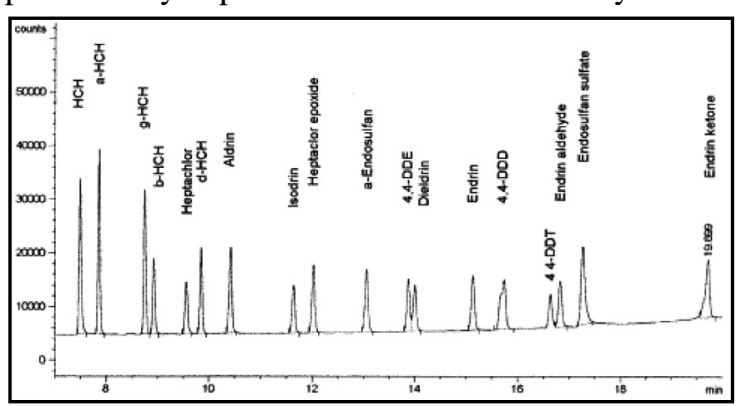

Figure 3: Typical GC-ECD chromatogram of standard solution of insecticides, concentration $10 \mu \mathrm{g} \mathrm{l}^{-1}$. 
Table 8. Analytical lines used for the determination of metals with AAS

\begin{tabular}{lcccccccc}
\hline Metal & $\mathrm{As}$ & $\mathrm{Cd}$ & $\mathrm{Cr}$ & $\mathrm{Cu}$ & $\mathrm{Co}$ & $\mathrm{Fe}$ & $\mathrm{Pb}$ & $\mathrm{Mn}$ \\
\hline Line $(\mathbf{n m})$ & 193 & 228.8 & 357.9 & 324.8 & 242.5 & 248.3 & 283.3 & 279.5 \\
\hline Metal & $\mathrm{Mo}$ & $\mathrm{Ni}$ & $\mathrm{Va}$ & $\mathrm{Zn}$ & $\mathrm{Ti}$ & $\mathrm{Ba}$ & $\mathrm{Al}$ & $\mathrm{Hg}^{*}$ \\
\hline Line $(\mathbf{n m})$ & 313.3 & 232 & 318.4 & 213.9 & 364.3 & 553.6 & 309.3 & 253.7 \\
\hline
\end{tabular}

Table 9. Detection limits for metals

\begin{tabular}{lcccccccc}
\hline Metal & $\mathrm{As}$ & $\mathrm{Cd}$ & $\mathrm{Cr}$ & $\mathrm{Cu}$ & $\mathrm{Co}$ & $\mathrm{Fe}$ & $\mathrm{Pb}$ & $\mathrm{Mn}$ \\
\hline $\mathbf{D L}\left(\boldsymbol{\mu \mathbf { g ~ l } ^ { - \mathbf { 1 } } )}\right.$ & 1 & 0.025 & 0.18 & 0.36 & 0.8 & 1 & 0.8 & 0.27 \\
\hline Metal & $\mathrm{Mo}$ & $\mathrm{Ni}$ & $\mathrm{Va}$ & $\mathrm{Zn}$ & $\mathrm{Ti}$ & $\mathrm{Ba}$ & $\mathrm{Al}$ & \\
\hline $\mathbf{D L}\left(\boldsymbol{\mu} \mathbf{g ~ l}^{-\mathbf{1}}\right)$ & 0.13 & 0.40 & 1 & 0.35 & 15 & 11 & 16 & \\
\hline
\end{tabular}

Table 10. Analytical conditions for the determination of $\mathrm{Hg}$ with AAS- FI/MHS

\begin{tabular}{llll}
\hline Wavelength & 253.7 (HCL Mercury lamp) & Reagents: & \\
Slit & $0.7 \mathrm{~nm}(\mathrm{Low})$ & Carrier solution & $3 \%(\mathrm{v} / \mathrm{v}) \mathrm{HCL}$ \\
Integration time & $20 \mathrm{sec}$. & Reducing agent & $1.1 \% \mathrm{SnCl}_{2} \mathrm{in} \%(\mathrm{v} / \mathrm{v}) \mathrm{HCL}$ \\
Data processing & Smoothing: $0,5 \mathrm{sec}$. & Sample solution & $\mathrm{Hg}^{2+}$ in acidified solution. \\
Cell temperature & $100^{\circ} \mathrm{C}$ & Flow of carrier gas & $95 \mathrm{ml} \mathrm{min}^{-1}$ \\
Sample volume & $500 \mu \mathrm{l}$ & Replicates per sample & 5 \\
\hline
\end{tabular}

\section{Pentachlorophenol (PCP)}

Sampling. Water samples are collected in 1-1 amber glass vials and kept at $4{ }^{\circ} \mathrm{C}$.

Standards. Certified PCP standards from Restek and Chemservice are used. The standard solutions are prepared in methanol.

Sample preparation. Samples are acidified to $\mathrm{pH}<$ 2 with $\mathrm{HCl}$ and filtered through a GF/F $0.7 \mu \mathrm{m}$ glass microfiber filter (Whatman, England). C18 cartridges (Waters, USA) are conditioned with $10 \mathrm{ml}$ acetonitrile, $10 \mathrm{ml}$ methanol and $5 \mathrm{ml}$ buffer solution $(\mathrm{pH} 2.5)$ and the sample is loaded with an approximate flow rate of $10 \mathrm{ml} \mathrm{min}^{-1}$. The sorbent dries for $5 \mathrm{~min}$ and PCP is eluted with $4 \times 2 \mathrm{ml}$ methanol. The methanol is removed under a gentle stream of nitrogen until the volume reaches $1 \mathrm{ml}$.

Analytical. The analysis is accomplished by use of the HPLC/DAD system described above. The mobile phase consists of (A) buffer solution $\mathrm{KH} 2 \mathrm{PO} 4-\mathrm{H} 3 \mathrm{PO} 41 \mathrm{mM}, \mathrm{pH}=2.5$ and (B) methanol. The gradient program is the following: $\mathrm{t}=0 \mathrm{~min}, 80 \% \mathrm{~A}, 20 \% \mathrm{~B}>\mathrm{t}=15 \mathrm{~min}, 40 \% \mathrm{~A}$, $60 \% \mathrm{~B}>\mathrm{t}=18 \min , 10 \% \mathrm{~A}, 90 \% \mathrm{~B}$

The mobile phase flow rate is $1.5 \mathrm{ml} \mathrm{min}^{-1}$, the injected sample volume $100 \mu \mathrm{l}$ and the column is kept at ambient temperature $(200 \mathrm{C})$. PCP is detected at wavelength $302 \mathrm{~nm}$. The mean recovery of pentachlorophenol is $86.5 \%$ and the DL $0.92 \mu \mathrm{g} \mathrm{l}^{-1}$.

\section{Metals}

Sampling. Water samples are collected in 500-ml polyethylene vials and are acidified with $\mathrm{HNO}_{3}$ to pH 1.

Sample preparation. The total acid extractable matter of the metals $\mathrm{As}, \mathrm{Cd}, \mathrm{Cr}, \mathrm{Cu}, \mathrm{Co}, \mathrm{Fe}, \mathrm{Mn}$, $\mathrm{Mo}, \mathrm{Ni}, \mathrm{Pb}, \mathrm{V}$ and $\mathrm{Zn}$ is determined after digestion of samples for 12 hours in $70{ }^{\circ} \mathrm{C}$ (Haswell, 1991). The sample preparation for the determination of total and dissolved $\mathrm{Hg}$ is presented elsewhere (APHA, 1992; Perkin Elmer, 1990)

Analytical. The determination of the metals: As, $\mathrm{Cd}, \mathrm{Cr}, \mathrm{Cu}, \mathrm{Co}, \mathrm{Fe}, \mathrm{Mn}, \mathrm{Mo}, \mathrm{Ni}, \mathrm{Pb}, \mathrm{V}$ and $\mathrm{Zn}$ (dissolved and total acid extractable) is made using a atomic absorption spectrophotometer equipped with a Zeeman THGA graphite furnace. The determination of $\mathrm{Ba}, \mathrm{Ti}$ and $\mathrm{Al}$ is performed by Inductively Coupled Plasma - Atomic Emission Spectrometry (ICP-AES). The analytical lines used are presented in Table 8, and the detection limits in Table 9. For As, $1 \mu \mathrm{g}$ Pd and for $\mathrm{Cd}$ and $\mathrm{Pb}, 1 \mu \mathrm{g} \mathrm{Pl}$ were used as chemical modifiers. Detailed analytical conditions are described elsewhere (Lekkas, 2000b; Perkin Elmer, 1982). The determination of $\mathrm{Hg}$ is made using an Atomic Absorption Spectrophotometer equipped with a Flow Injection Mercury/Hydride System (AAS- FI/MHS) (Perkin Elmer 5100 ZL with Perkin Elmer FIAS 100). The analytical conditions are presented in Table 10. The recovery of the method for $\mathrm{Hg}$ determination is $98.9 \pm 4 \%$ and the DL $0.2 \mu \mathrm{g} \mathrm{l}^{-1}$ (Pavlogeorgatos, 2001). 
Table 11. Analytical conditions for determination of total organotin compounds

\begin{tabular}{lcccc}
\hline Stage & $\begin{array}{c}\text { Temperature } \\
\boldsymbol{\theta}\left({ }^{\mathbf{(}} \mathbf{C}\right)\end{array}$ & $\begin{array}{c}\text { Duration of temperature } \\
\text { increase }(\mathbf{s e c})\end{array}$ & $\begin{array}{c}\text { Duration at temperature } \\
\boldsymbol{\theta}(\mathbf{s e c})\end{array}$ & $\begin{array}{c}\text { Ar flow } \\
\text { Ar flow }\left(\mathbf{m l} \mathbf{~ m i n}^{-\mathbf{1}}\right)\end{array}$ \\
\hline Drying 1 & 120 & 5 & 5 & 250 \\
Drying 2 & 130 & 15 & 15 & 250 \\
Pyrolysis & 1200 & 15 & 25 & 250 \\
Vaporization & 2000 & 1 & 4 & 0 \\
Cleaning & 2400 & & 2 & 250 \\
\hline
\end{tabular}

\section{Organotins}

Sampling. Water samples (1 1 ) are collected in dark glass bottles and immediately acidified with $\mathrm{HCl}$ to $\mathrm{pH} 2$.

Sample preparation. A.Total Organotins. The procedure involves acidification of water samples with $50 \mathrm{ml}$ of glacial acetic acid and extraction with 10 $\mathrm{ml}$ of toluene. After the extraction, the solvent layer is transferred in a glass bottle and is preconcentrated under a gentle air flow to $1 \mathrm{ml}$. Within this procedure tributyltin (TBT), triphenyltin (TPhT) and some dibutyltins (DBT) are extracted but not monobutyltin (MBT) or inorganic tin (Sn) (Dadfarnia et al., 1994). Recoveries tests are done in order to assure this hypothesis. The recoveries are for TBT $(98 \pm 4 \%)$, TPhT $(105 \pm 2 \%)$, DBT $(76 \pm 2)$, MBT $(0 \%)$, Sn $(0 \%)$.

B. Organotin speciation. The $\mathrm{pH}$ of 11 of water sample is adjusted at 5.00 with $13.6 \mathrm{~g}$ of sodium acetate and few $\mathrm{ml}$ of acetic acid and it is transferred in a 1-1 separation funnel. $2.5 \mathrm{ml}$ of NaBEt4 $0.4 \%$ w/v (prepared every day) and $5 \mathrm{ml}$ of hexane is added and the mixture is shaken manually for $10 \mathrm{~min}$. After phase separation (20 $\mathrm{min})$, the hexane phase is collected in a glass vial, protected from light and stored at $-20^{\circ} \mathrm{C}$.

Analytical. A.Total Organotins. A Perkin Elmer atomic absorption spectrophotometer, model 5100 equipped with a Zeeman THGA graphite furnace is used. The operating conditions are lamp current $32 \mathrm{~mA}$, wavelength $286.3 \mathrm{~mm}$, slit $0.7 \mathrm{~nm}$ and rhenium has been chosen as chemical modifier. In order to achieve a lower detection limit the hot-injection technique has been utilized. The detection limit of the method is 0.001 $\mu \mathrm{g} \mathrm{l}^{-1}$. The analytical conditions for determination of organotins are presented in Table 11.

B. Organotin speciation. A Fisons GC 8000 with FPD Detector 800 is used. The column is DB-1 10 $\mathrm{m} \times 0.32 \mathrm{~mm}$, the carrier gas is $\mathrm{He}$ and the injection technique is split/splitless. The analytical con- ditions are presented elsewhere (CarlierPinasseau et al., 1996). The recoveries of the method range from $69.0 \%-72.4 \%$ for MBT, 94.8 $\%-98.6 \%$ for DBT, $95.5 \%-103 \%$ for TBT, 93.2 $\%-101 \%$ for DPT and $97.3 \%-105 \%$ for TPT.

\section{CONCLUSIONS}

Analytical methods by means of GC with ECD, NPD, FPD and MS detection, PAT concentration, HPLC/DAD and AAS were optimized in order to be routinely used for the determination of trace concentrations of 130 toxic pollutants in drinking and surface water. Wherever possible, reduction of analysis time and amounts of toxic solvents use was attempted, either by small sample volume/elimination of the evaporation step (in the case of CBPs), or by use of the PAT technique for sample preparation (in the case of VOCs), or by selection of a low toxicity solvent such as ethyl acetate (in the case of insecticides). The recoveries and detection limits obtained for the determination of the majority of the compounds were satisfactory. Low recoveries observed in some cases are attributed to very low levels of concentrations tested, in combination with problems during the sample preparation procedure (in the cases of CBPs, insecticides and herbicides) or due to the volatility of the compounds (in the case of the PAT procedure). In conclusion, all extraction techniques described (solid phase extraction, liquid-liquid extraction and PAT) in combination with the chromatographic determination applied for the toxic pollutants resulted in the efficient isolation of the compounds from water samples. Although the recoveries of some of the compounds were low, the limits of detection complied with the European legislation concerning their occurrence in surface water. 


\section{REFERENCES}

Albanis T., Hela D., Sakellarides T. and Konstantinou I. (1998), Pesticides Residues in Surface Water and Rainfall of Imathia (N. Greece), Proceedings of International Conference Protection and Restoration of the Environment IV, Halkidiki Makedonia Greece, 1-4 July 1998.

APHA, AWWA, WPCF (1992), Standard Methods for the Examination of Water and Wastewater (18th ed.), American Public Health Association, Washington, USA.

Cancho B., Ventura F. and Galceran M. (1999), Behavior of halogenated disinfection by-products in the water treatment plant of Barcelona, Spain, Bull. Env. Contam. Toxicol., 63, 610-617.

Carlier-Pinasseau C., Lespes G. and Astruc M. (1996), Determination of butyltin and phenyltin by GCFPD following ethylation by NaBEt4, Applied Organometallic Chemistry, 10, 505-512.

Cerejeira M.J., Viana P., Batista S., Pereira T., Silva E., Valerio M.J., Silva A., Ferreira M., SilvaFernandes A.M., Pesticides in Portuguese surface and ground waters, Wat. Res., 37, 5, 1055 1063.

Chen W.J. and Weisel C.P. (1998), Halogenated DBP concentrations in a distribution system, J AWWA, 90, 4, 151-163.

Council of the European Community, 1980, Directive Relating to the Quality of Water Intended for Human Consumption (80/778/EEC), Official Journal N. 229/ 11.

Dadfarnia S., Thompson K. and Hoult G. (1994), Development of a simple method for the determination of toluene extractable organotin by Electrothermal Atomic Absorption, J. Anal. At. Spectrom., 9, 7-9.

EC (2000), Directive of the European Parliament and of the council 2000/60/EC establishing a framework for community action in the field of water policy, Official Journal C513, 23/10/2000.

EEC (1982), Communication from the Commission to the Council on dangerous substances which might be included in List I of Council Directive 76/464/EEC, Official Journal C176, 14/07/1982, pp. 3-10.

Fent, K. and Hunn, J. (1995), Organotins in freshwater harbors and rivers: Temporal distribution, annual trends and fate, Environmental Toxicology and Chemistry, 14, 1123-1132.

Golfinopoulos S. and Nikolaou A. (2001), Disinfection by-products and volatile organic compounds in the water supply system of Athens, Greece, Env. Sci. Health A36, 483-499.

Golfinopoulos S.K., Lekkas T.D. and Nikolaou A.D. (2001), Comparison of methods for determination of volatile organic compounds in drinking water, Chemosphere, 45, 3, 275-284.

Golfinopoulos S., Nikolaou A., Kostopoulou M., Xylourgidis N., Vagi M. and Lekkas D. (2003), Organochlorine pesticides in the surface waters of Northern Greece, Chemosphere, 50, 507516.

Haswell S. (1991), Atomic Absorption Spectrometry: Theory, Design and Applications, Analytical Spectroscopy Library, 5, Elsevier, Oxford.

Kostopoulou M., Golfinopoulos S., Nikolaou A., Xilourgidis N. and Lekkas T. (2000), Volatile organic compounds in the surface waters of Northern Greece, Chemosphere, 40, 527-532.

Kotrikla A. and Lekkas T. (2001), The HPLC separation of two mixtures of neutral pesticides: effects of temperature, gradient steepness and flow rate, J. Liq. Chrom. \& Rel. Technol. 24, 543-553.

Lekkas T. (2000a), National program for pollution reduction for the compounds of List II, candidates for List I, C176, 14/07/1982/EEC, according to article 7 of 76/464/EEC Directive, Water and Air Quality Laboratory, University of the Aegean, Mytilene, Greece.

Lekkas T. (2000b), National program for pollution reduction for the compounds of List II (Metals), C176, 14/07/1982/EEC, according to article 7 of 76/464/EEC, Water and Air Quality Laboratory, Department of Environmental Studies, University of the Aegean, Mytilene, Greece.

Lekkas T.D. (2003), Occurrence and Regulation of Chlorination By-Products in Drinking Water. In The Handbook of Environmental Chemistry, Vol. 5 Haloforms and Related Compounds in Drinking Water, Otto Hutzinger, Editor-in-Chief; Springer: Bayreuth, Germany, 193-214.

Nikolaou A., Lekkas T., Golfinopoulos S. and Kostopoulou M. (2002a), Application of different analytical methods for determination of volatile chlorination by-products in drinking water, Talanta, 56, 717-726. 
Nikolaou A., Golfinopoulos S., Kostopoulou M. and Lekkas T. (2002b), Determination of HAAs in water by acidic methanol esterification-GC-ECD method, Wat. Res., 36,1089-1094.

Pavlogeorgatos G. (2001), The fate of mercury in an activated sludge pilot plant, PhD thesis, Department of Environmental studies, University of the Aegean, Mytilene, Lesvos, Greece (in Greek).

Perkin Elmer (1982), Analytical Methods for Atomic Absorption Spectrophotometry, Perkin Elmer, Norwalk, Connecticut, U.S.A., 0303-0152.

Perkin Elmer (1990), Atomic Absorption Technical Summary, No. TSAA-10C, Perkin Elmer USA.

Sabik H. and Jeannot R. (2000), Stability of Organophosphorous Insecticides on Graphitized Carbon Black Extraction Cartridges used for Large Volumes of Surface Waters, J. Chromatogr. A, 879, 73-82.

Richardson S.D. (2002), The role of GC-MS and LC-MS in the discovery of drinking water disinfection by-products, J. Environ. Monitor., 4, 1-9.

USEPA (1998) National Primary Drinking Water Regulations: Disinfectants and Disinfection ByProducts Notice of Data Availability. Office of Ground Water and Drinking Water; 1998. http://www.epa.gov/OGWDW/mdbp/dis.html

WHO (1995), Desinfection de l' eau, Local authorities, Health and Environment briefing pamphlet series, No 3. 